\section{Smiljana Komar}

University of Ljubljana, Slovenia
2019, Vol. 16 (1), 101-122(164)

revije.ff.uni-lj.si/elope

doi: 10.4312/elope.16.1.101-122

UDC: $811.111^{\prime} 355: 37.09 .3$

\title{
The Challenges, Methods and Results of Teaching GB Pronunciation to Slovene EFL Students
}

\begin{abstract}
The paper presents and discusses the results of a study whose main purpose was to test the oral production of General British (GB) sounds in connected speech by Slovene BA students of English. Previous studies in contrastive English-Slovene pronunciation were mainly concerned with the perception and production of individual sounds. Our study, on the other hand, focused on the production of GB sounds in connected speech. We were interested in the state of affairs of English pronunciation before and after a 60-hour intensive and systematic theoretical and practical instruction of English pronunciation. The results confirmed out initial two hypotheses that the influences of L1 phonological and phonetic system, orthography and General American pronunciation were stronger before the instruction, and that the phonemic transcription has a very positive influence on the acquisition of foreign sounds in EFL students.
\end{abstract}

Key words: foreign language learning; English-Slovene pronunciation error analysis; teaching English phonetics and phonology; phonemic transcription

\section{Izzivi, metode in rezultati poučevanja standardne britanske izgovarjave pri slovenskih študentih angleščine kot tujega jezika}

POVZETEK

Članek prikazuje in obravnava rezultate raziskave, katere namen je bil preveriti izgovarjavo standardnih britanskih glasov v strnjenem govoru pri slovenskih študentih angleščine na prvi bolonjski stopnji študija. Predhodne kontrastivne angleško-slovenske raziskave izgovarjave so se osredotočale predvsem na percepcijo in produkcijo posameznih glasov. Z našo raziskavo pa smo želeli ugotoviti, kakšna je izgovarjava standardnih britanskih glasov v strnjenem govoru. Zanimalo nas je stanje izgovarjave pred in po šestdeseturnem intenzivnem in sistematičnem pouku teoretičnih in praktičnih vsebin angleške izgovarjave. Rezultati so potrdili naši dve izhodiščni hipotezi: prvič, vplivi glasoslovnih značilnosti maternega jezika, pisave ter ameriške angleščine so večji pred začetkom pouka, in drugič, fonemska transkripcija ima pozitiven vpliv na usvajanje tujih glasov pri študentih angleščine kot tujega jezika.

Ključne besede: učenje tujih jezikov; angleško-slovenska analiza napak izgovarjave; poučevanje angleške fonetike in fonologije; fonemska transkripcija 


\section{Introduction}

In the era when English has become the international language of mass communication or the so-called Lingua Franca, the teaching of the British standard pronunciation to EFL students presents many challenges, from linguistic to motivational and pedagogical.

This paper focuses mainly on linguistic challenges although the motivational and pedagogical issues will also be addressed in the context of the English pronunciation taught at the English Department at the Faculty of Arts, University of Ljubljana. The course on English Phonetics, Phonology and Pronunciation is scheduled in the first year of BA studies. The pronunciation model and hence the target pronunciation for L2 Slovene students has always been the General British (GB) pronunciation, formerly known as Received Pronunciation (RP). Most Slovene students of English, whose general knowledge of English is at the CEFR level B2, speak a hybrid between American and British varieties with features arising from their L1 (Šuštaršič 2005, 70). Bridging the gap between the prescribed pronunciation model and the students' pronunciation presents the first major challenge in the teaching of English pronunciation to Slovene students.

The second challenge concerns the awareness and acquisition of all the features of the selected pronunciation model. To meet this requirement, the practical teaching of English pronunciation to Slovene students of English consists of several strategies which include (i) different ear-training exercises whose purpose is to improve the learners' perception of GB phonemes, (ii) phonemic (and to some extent also phonetic) transcription of written texts, (iii) reading phonemically transcribed texts, and (iv) reading regular texts. All these strategies are supported by the theory of GB phonology and phonetics. In recent years, several perception and production studies have been conducted (Šuštaršič 2005; Stopar 2015, 2017, 2019; Komar 2017) and their findings suggest different degrees of overlap between the perception, oral production, spelling and phonemic transcription of sounds.

In this paper we present the results of a study the purpose of which was to validate the findings of previous studies, as well as to detect other reasons for typical pronunciations errors made by Slovene EFL students. Different from previous studies, which focused on the perception and production of individual sounds in the context of one word, the present study focused on the pronunciation of sounds in connected speech, more precisely, in the linguistic context of one sentence.

The paper presents an overview of the findings in perception, production and acquisition of foreign sounds (Section 2), comparison of General British and standard Slovene phonological and phonetic systems (Section 3), predicted errors made by 
Slovene EFL speakers (Section 4), hypotheses and methodology of the study (Section 5), results and their discussion (Section 6 and Section 7), and Conclusion (Section 8).

\section{Research on Perception, Production and Acquisition of Foreign Sounds}

Several factors govern the acquisition of foreign sounds. The ability to discriminate between L1 and L2 sounds is among the most important ones. It is often hindered by the influence of the phonemic and phonetic system of L1, since the judgements on similarity or difference between two phonemes are made against the background knowledge and phonemic awareness of the mother tongue. Flege (1995) and Escudero (2002) both believe that the majority of production errors are based on a false perception of L2 phonemes. Similarly, L2 speakers can create new L2 phonemes solely by relying on some phonetic or phonemic category of their L1 (Flege 1995; Best 1995). Escudero (2002) also suggests that foreign learners can learn to perceive foreign contrasts. Stopar $(2015,2017,2019)$, who has analysed the pre-training and post-training perception of GB monophthongs by Slovene EFL students, confirms that perception of foreign sounds can be successfully acquired by systematic perception training even in those foreign vowels which share the same vowel space with $\mathrm{L} 1$ vowels.

According to Baker and Trofimovich (2006) and Bion et al. (2006), who have looked into the relationship between the perception and production of L2 vowels, successful perception results in successful production of sounds. Other studies (see Lord 2005; Lipinska 2013) suggest that explicit instruction in English phonetics and phonology improves learners' production of sounds.

There has been very little research in second language acquisition on the influence of L1 orthography on the perception and production of L2 phonemes. Bassetti (2008) argues that orthographic input of L1 interacts with L2 acoustic input, leading to nonnative pronunciations which cannot be attributed to the influence of L1 phonological and phonetic system. Research has shown that learners' mental representations of L2 phonemes created under the influence of orthographic input may affect their perception in such a way that they hear non-existing phonemes or phonetic features (see Matthews and Brown 2004). These mental representations are so strongly imprinted in the brain that they affect the production and perception also in the absence of the orthographic input.

Practising phonemic transcription of a foreign language whose grapheme-phoneme correspondence is opaquer (e.g. English) is particularly beneficial for those EFL speakers whose L1 exhibits a close grapheme-phoneme correspondence (e.g. Slovene). Phonemic transcription not only reflects pronunciation errors resulting 
from orthographic input, but also develops L2 phonetic awareness in L1 learners. Studies by Wells (1996), Šuštaršič (2005), Lintunen (2005) and Komar (2017) all confirm the positive effect of phonemic transcription on L2 pronunciation of a foreign language with an opaque-grapheme correspondence. The correlation between the phonemic transcription and the pronunciation of consonants is stronger than that between the phonemic transcription and vowels.

\section{General British (GB) vs. Standard Slovene (StS) Phonological System}

\subsection{Vowels}

Studies in contrastive English-Slovene analysis of the vocalic system have shown that the two languages differ not only in the number of vocalic phonemes but also in their quality and quantity (see Šuštaršič, Komar and Petek 1995; Šuštaršič 2005; Stopar 2015). Stopar (2015: 87) presents the comparison between StS and GB monophthongs as shown in Figure 1.

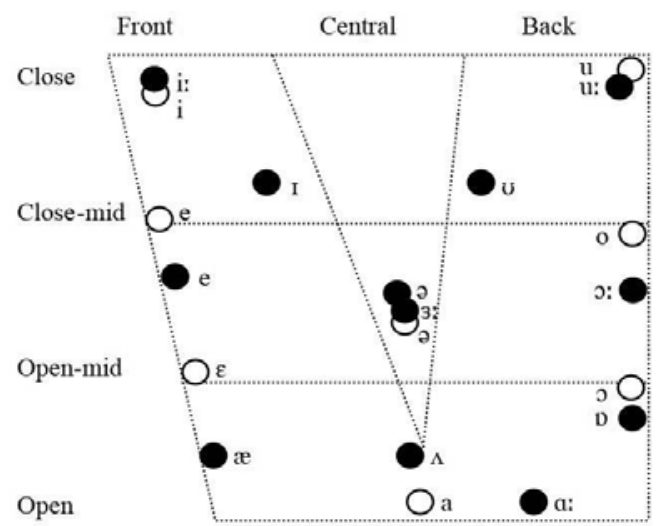

Figure 1. Vowel chart with StS (white dots) and GB (black dots) monophthongs.

Several studies (Šuštaršič 2005; Collins, Šuštaršič, and Komar 2014; Stopar 2015) in contrastive analysis of $\mathrm{StS}$ and $\mathrm{GB}$ vowel systems have shown that the most difficult GB vowel contrast for Slovene speakers of English to master is the contrast between the front close-mid to open-mid /e/ - or the DREss-vowel - and the front just above open $/ \mathfrak{x} /$ - or the TRAP vowel - (transcribed in Cruttenden (2014) as /a/) ${ }^{1}$. The contrast is even more challenging since there is a similar vowel contrast in StS between /e/ (front close-mid) and / $\varepsilon /$ (front open-mid). Contrary to the expectation that Slovene EFL speakers would simply replace the two GB vowels with the StS

$1 \quad$ DRESS and TRAP are two of 27 keywords introduced by Wells (1982) to represent a large number of words with the same vowel. Throughout the paper these keywords are used to refer to GB vowels. 
equivalents, this is rarely the case ${ }^{2}$. It seems that the $\mathrm{StS} / \mathrm{e} /$ vowel is perceived by Slovene EFL speakers as too close to be used instead of the GB DREss-vowel. Instead, both GB vowels are perceived, and as a consequence also pronounced, as the openmid front vowel $/ \varepsilon /$. This often results in homophonic realizations of minimal pairs, such as for example bet/bat//bet/ or set/sat/*set/.

Slovene EFL learners may also find the central to back, open to mid-open vowel space problematic since the GB STRUT-vowel / $\Lambda$ / and the GB PALM-vowel /a:/ may both be pronounced with the Slovene central open /a/ vowel. In addition, the GB STRUT-vowel is, under the influence of the letter $\langle 0\rangle$, often mispronounced as the GB LOT vowel /p/.

There are two GB vowels in the back, open-mid to close-mid vowel space - GB Lот / $\mathrm{p} /$ and GB тноUgнт / $\mathrm{o}: /$ - which have two very closely corresponding StS vowels: $/ \mathrm{J} /$ and $/ \mathrm{o} /$, respectively. Although the situation mirrors the front vowel opposition between /e/ and /æ/, neutralization between $/ \mathrm{p} /$ and $/ \mathrm{\rho} / /$ does not occur. These two GB back vowels are not problematic either in terms of production or perception (see Stopar 2017). Under the influence of General American (GA), however, the GB THOUGHT vowel is often pronounced as the GA/a/, whereas the GB PALM-vowel is replaced by the GB TRAP-vowel in the words belonging to the BATH lexical set.

As presented in Figure 1, there are no corresponding StS vowels to GB KIT /I/ and GB ғоот / / vowels. These two vowels are often replaced by the nearest $\mathrm{StS}$ vowels, that is $/ \mathrm{i} /$ and $/ \mathrm{u} /$ which are both too close, as well as too front and back, respectively.

Maintaining the length of the GB long monophthongs before voiced consonants or silence is also a challenge for Slovene EFL learners since length is not a distinctive phonological feature in StS. In addition, all StS obstruents are voiceless and fortis before silence or another voiceless consonant. Hence, Slovene EFL learners often pronounce long GB monophthongs before silence or voiced consonants as too short, thus not differentiating between pairs of English words, such as bead/beat, hard/heart, cord/caught, loselloose.

There are no phonemic diphthongs in $\mathrm{St} S$. The nearest equivalents to GB closing diphthongs in $\mathrm{StS}$ are clusters of vowels followed by /j/ or $[w]^{3}$ : [ej, oj, oj, aj, uj; ew, $\varepsilon w, a w, ~ o w]$. The StS diphthongs [aj, ej, oj, aw] are equivalent to GB diphthongs /aI,

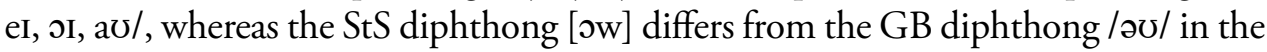
first element which is in $\mathrm{StS}$ back and open-mid. There are no equivalents whatsoever to GB centring diphthongs. These represent a problem for Slovene EFL learners as

Sometimes this can happen with Slovene speakers whose native accents do not recognize the two vowels, but only one. $[w]$ is a bilabial realization of the labio-dental approximant $/ v /$. 
they tend to pronounce them by $\mathrm{St} S$ monophthongs $/ \mathrm{i}, \varepsilon, \mathrm{u} /$ followed by $/ \mathrm{r} /$ when there is the letter $<\mathrm{r}>$ in the spelling, or without the alveolar approximant when there is no letter $<r>$ in the spelling.

\subsection{Consonants}

The phonological consonantal systems of the two languages are presented in Table 1 below.

TABLE 1. StS (grey) and GB (black) consonants.

\begin{tabular}{|c|c|c|c|c|c|c|c|c|c|}
\hline & 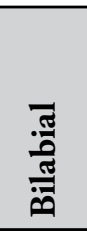 & 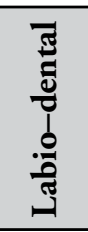 & 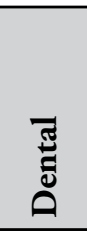 & 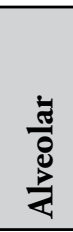 & 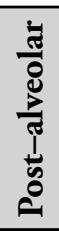 & 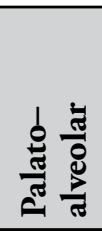 & 胥 & $\frac{\frac{5}{5}}{2}$ & $\begin{array}{l}\bar{\Xi} \\
\text { ज्ञ }\end{array}$ \\
\hline Plosive & $\begin{array}{l}\mathbf{p} \mathbf{p} \\
\mathbf{b} \mathbf{b}\end{array}$ & & t d & t d & & & & $\begin{array}{l}\mathrm{k} \mathbf{k} \\
\mathrm{g} \mathbf{g}\end{array}$ & \\
\hline Affricate & & & & ts & & $\begin{array}{l}\mathrm{t} \int \mathrm{t} \int \\
\mathrm{d} 3 \mathrm{~d}\}\end{array}$ & & & \\
\hline Fricative & & $\mathbf{f} \mathbf{f} \mathbf{v}$ & $\boldsymbol{\theta}$ д & $\begin{array}{l}s \mathbf{s} \\
\mathrm{z} \mathbf{z} \\
\end{array}$ & & $\begin{array}{l}\iint \\
33 \\
\end{array}$ & & $\mathbf{x}$ & $\mathbf{h}$ \\
\hline Nasal & $\mathbf{m} \mathbf{~ m}$ & & $\mathrm{n} \mathbf{n}$ & & & & & $\eta$ & \\
\hline Tap & & & & f & & & & & \\
\hline Approximant & $\mathbf{w}$ & 0 & & & $\mathbf{r}$ & & $\mathbf{j} \mathbf{j}$ & & \\
\hline $\begin{array}{l}\text { Lateral } \\
\text { approximant }\end{array}$ & & & & 11 & & & & & \\
\hline
\end{tabular}

Systemic differences between StS and GB consonants include the following:

- lack of consonants,

- additional consonants,

- different places of articulation,

- different manners of articulation.

There are three GB consonants which are non-existent in the StS. These are the voiced and voiceless dental fricatives $/ \partial /$ and $/ \theta /$, and the labio-velar (also referred to as bilabial) approximant $/ \mathrm{w} /$. There is also no voiced labio-dental fricative /v/ in StS. The GB velar nasal $/ \mathrm{y} /$ occurs in StS only as an allophone of the dental nasal $/ \mathrm{n} /$ when followed by a velar consonant. As a result, Slovene EFL speakers tend to pronounce the GB velar nasal followed by a velar plosive also in distributions where the velar plosive is mute.

In addition to the voiced and voiceless palato-alveolar affricates $/ \mathrm{d} z /$ and $/ \mathrm{t} /$, there is a voiceless alveolar affricate /ts/in StS. 
StS consonants with different places of articulation than their near equivalents in GB are the voiced and voiceless plosives $/ \mathrm{d} /$ and $/ \mathrm{t} /$, and the nasal $/ \mathrm{n} /$ which all have dental place of articulation instead of alveolar. The nearest equivalent to the GB glottal fricative /h/ is the $\mathrm{St} S$ velar fricative / $\mathrm{x} /$.

Consonants with different manners of articulation in $\mathrm{StS}$ concern the voiced alveolar $\operatorname{tap} / \mathrm{f} /$, and the voiced labio-dental approximant $/ \mathrm{v} /$ which Slovene EFL speakers often mispronounce as the GB labio-velar approximant /w/, as in the word vowel $I^{*}$ wawall, for example.

\subsection{Allophonic differences}

With respect to allophonic differences concerning consonants, StS differs from GB primarily in:

- the lack of aspiration of voiceless plosives /p, t, k/ in stressed, syllable-initial and pre-vocalic positions;

- the lack of glottal reinforcement of voiceless plosives $/ \mathrm{p}, \mathrm{t}, \mathrm{k} /$ and voiceless affricate $/ \mathrm{t} /$;

- the lack of dark [1];

- nasals and approximants are not devoiced by the preceding voiceless and fortis obstruent;

- voiced obstruents in word-final position or followed by a voiceless obstruent are voiceless and fortis;

- voiceless obstruents followed by a voiced obstruent are voiced and lenis;

\section{Predicted Errors Made by Slovene EFL Speakers}

On the basis of the above-described phonemic and allophonic differences between $\mathrm{StS}$ and GB, we can predict the following pronunciation errors.

\subsection{Vowels}

- GB long vowels will be pronounced too short before lenis consonants,

- GB short vowels /I, $\mho /$ will be replaced by StS equivalents /i, u/,

- GB TRAP vowel /æ/ will be replaced by StS front open-mid $/ \varepsilon /$,

- GB strut vowel $/ \Lambda /$ will replaced by $/ 3: /$ or $/ \mathrm{p} /$ - the latter mainly under the influence of the letter $<0>$ in the spelling,

- GB centring diphthongs /ıə, eə, və/ will be replaced by StS monophthongs /i, $\varepsilon, \mathrm{u} /$ followed by $/ \mathrm{r} /$ when there is the letter $<\mathrm{r}>$ in the spelling.

\subsection{Consonants}

- GB dental fricatives / $\theta$, $\partial /$ will be pronounced as $\mathrm{St} S$ dental plosives / $\mathrm{t}, \mathrm{d} /$,

- GB glottal fricative /h/ will be pronounced as $\mathrm{StS}$ velar fricative /x/, 
- GB voiced labio-dental fricative /v/ will be pronounced as StS labio-dental approximant $/ v /$,

- GB velar nasal /y/ will always be followed by /k/ or /g/,

- GB voiced post-alveolar approximant/r/ will be pronounced in all positions.

\subsection{Allophonic features:}

- Lack of aspiration,

- Lack of glottal reinforcement,

- Fortition of voiced obstruents before voiceless obstruents and in word-final positions,

- Lenition of voiceless obstruents before voiced obstruents,

- Dark [1] pronounced as clear.

In addition, we expect the influence of General American English, particularly on the BATH-TRAP and THOUGHT-LOT vowel oppositions.

\section{The Study}

The present study investigates the influence of English pronunciation teaching on the production of sounds in connected speech by Slovene students of English as a foreign language. Its purpose is to examine the correlation between the pronunciation of a model sentence before and after a 30-hour course in English phonetics and phonology. The aim of the study is also to verify the findings of previous research in the perception of individual GB vowels (Stopar 2015, 2017, 2019), the relationship between the perception and production of GB vowels (Komar 2017), and the interference of L1 phonological and phonetic features on L2 pronunciation (Šuštaršič 2005).

In addition, the study was designed to test two hypotheses:

H1: The interference of L1 phonemic and phonetic system, orthography and General American English will be present in the reading of the sentence from orthography.

$\mathrm{H} 2$ : Systematic training of phonemic transcription has a positive influence on the production of sounds in connected speech.

\subsection{Method and Participants}

The study consisted of two production tests. In the first test, which took place at the beginning of the course in English phonetics and phonology (October 2018), the participants were given one orthographically transcribed English sentence. They were required to read and record it. The second test took place at the end of the course (January 2019). The course consisted of 30 hours of lectures and 30 hours of practical classes during which the students were trained in perception and production 
of General British phonemes, as well as in phonemic and phonetic transcription of individual words and sentences. They also became familiar with the basic rules of tonality, i.e. the division of utterances into intonation phrases. In the second test, the participants were given the same sentence which they had to transcribe phonemically, divide it into intonation phrases, read it and record it.

The sentence, which the students were required to read and record, contained all GB vowels and consonants (Collins, Šuštaršič, and Komar 2014, 142).

The sentence:

When the lighthouse keeper's lovely young daughter Thelma makes crab and lobster rolls, tourists come from far and near to enjoy fresh air, good food and searching for treasure on the beach.

The phonemic transcription:

I wen da laithaws ki:paz 'livlı 'jun 'da:ta 'Oelma | 'merks 'kreb an 'lobsta 'ravlz|

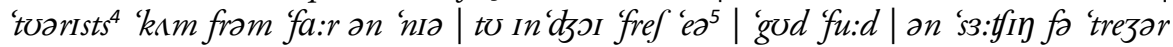
pn əə 'bi:t'।

All the participants in the study were first-year BA students of English at the Faculty of Arts, University of Ljubljana. In the first test, 120 students took part, whereas in the second test only 50 students participated. Participation in the study was on a voluntary basis. In order to monitor individual changes in pronunciation and to get more reliable results which would indicate possible improvement, we decided to include in the final analysis only those 50 students who took part in both tests.

For the evaluation of results, the auditory method was used. The evaluator had vast and long experience in teaching British English phonetics and phonology to Slovene speakers of English and carried out research in contrastive English-Slovene phonetics, phonology and prosody.

\section{Results}

For the purpose of comparison, we are going to present the results of both readings of the sentence simultaneously. The results are grouped according to the predicted errors.

Figure 1 shows the percentage of correct pronunciation of the sentence in the first and second reading, respectively.

The alternative correct pronunciation of <tourists $>$ is also /'to:rists/.

Although Cruttenden (2014) no longer recognizes the centring diphthong /eə/ and proposes a long, front, open-mid monophthong / $\varepsilon$ :/ instead, the Slovene students of English are still trained to perceive and produce the diphthong. 


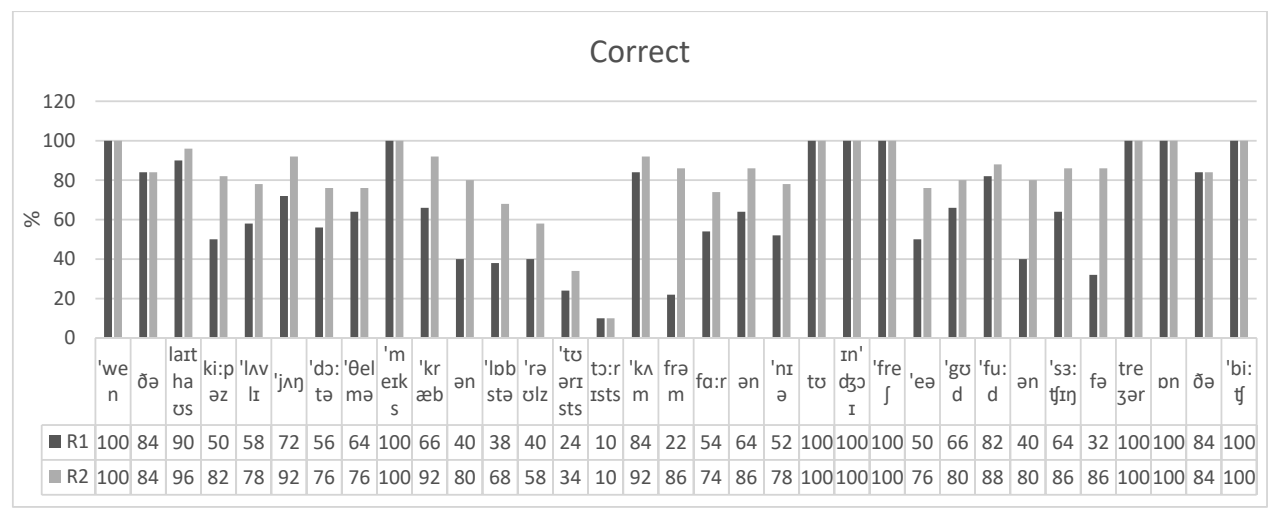

FIGURE 1. Overall pronunciation of the sentence - comparison of the first and second reading.

There were eight words which were correctly pronounced by all participants in both readings of the sentence. Five of them were lexical items (makes, enjoy, fresh, treasure, beach), whereas the remaining three were function words (when, to, on). In the majority of words, the participants made more than one pronunciation error.

Figure 2 shows the mean values of correct pronunciation of the whole sentence in the first and second reading. In the first reading, $66.24 \%$ of participants read the sentence correctly, while in the second reading the percentage was $82.48 \%$. This represents an increase of $16.24 \%$.

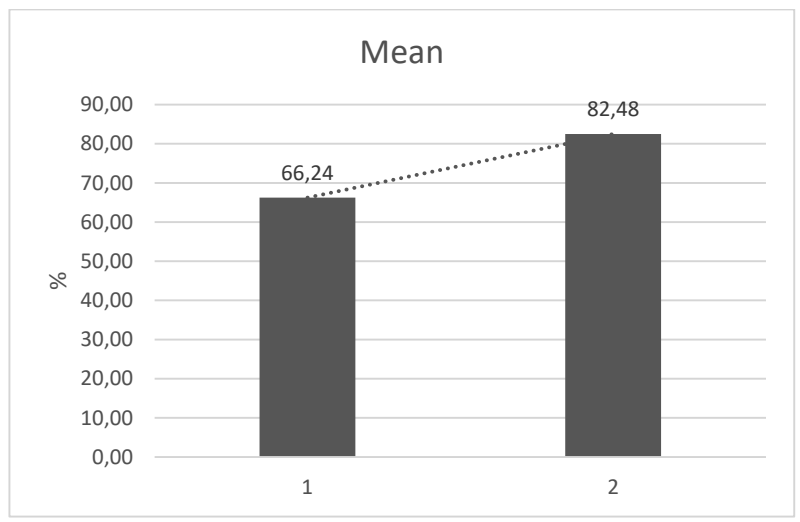

Figure 2. Mean values of correct pronunciation of the whole sentence in the first and second reading.

The pronunciation improvement of individual items in the second reading (see Figure 1 above) was best in the usage of weak forms of function words instead of their strong equivalents. The percentage of correct pronunciation in the second reading increased by $64 \%$ in from, $54 \%$ in for, and $22 \%$ in and. Among lexical items, the pronunciation most significantly improved in words keepers (by 32\%), lobster (by $30 \%$ ), crab and air (by 26\%). 


\subsection{Errors in Vowels}

The vowel quality of the word good and the vowel length in the word food were expected to be problematic for the participants. Table 2 shows that in the first reading $70 \%$ of participants pronounced the GB FOOT-vowel / $/$ correctly and only $30 \%$ replaced it with the $\mathrm{StS}$ vowel $/ \mathrm{u} /$. The percentage of correct pronunciation in the second reading increased to $82 \%$.

The correct length of the GB Goose-vowel /u:/ in the first reading was achieved by $92 \%$ of the participants, and improved by $4 \%$ in the second reading.

TABLE 2. Vowel quality and length.

\begin{tabular}{|l|c|c|c|c|}
\hline \multicolumn{3}{|c|}{ Reading 1 } & \multicolumn{2}{|l|}{ Reading 2 } \\
\hline Word & Correct \% & $/ \mathrm{u} / \%$ & Correct $\%$ & $/ \mathrm{u} / \%$ \\
\hline 'god & 70 & 30 & 82 & 18 \\
\hline 'fu:d & 92 & 8 & 96 & 4 \\
\hline Mean & $\mathbf{8 1}$ & & $\mathbf{8 9}$ & \\
\hline
\end{tabular}

Replacement of the GB TRAP / $/$ vowel by the StS vowel / $/ \varepsilon$ was expected to occur in the word crab. Table 3 shows that in the first reading the percentage of correct pronunciation of the vowel in question was $66 \%$. In the second reading, the correct pronunciation increased by $26 \%$ to $92 \%$.

TABLE 3. Replacement of the GB TRAP vowel with the Slovene vowel / $/ \varepsilon /$.

\begin{tabular}{|l|c|c|c|c|}
\hline \multicolumn{3}{|l|}{ Reading 1 } & \multicolumn{1}{|l|}{ Reading 2 } \\
\hline Word & Correct \% & $/ \varepsilon / \%$ & Correct \% & $/ \varepsilon / \%$ \\
\hline${ }^{\mathrm{k} k r æ b}$ & 66 & 34 & 92 & 8 \\
\hline
\end{tabular}

Mispronunciations of the GB STRUT / $\Lambda$ / vowel were expected to occur in words lovely, young and come. Table 4 presents the percentage of correct pronunciations, as well as two mispronunciations of the vowel in question. The mean value of correct pronunciation of the GB STRUT-vowel was 78\% in the first reading of the sentence, and $88.7 \%$ in the second reading. The worst result in the pronunciation of the vowel in question was in the word lovely where only $58 \%$ of participants pronounced the vowel correctly in the first reading. The most frequent mispronunciation of the vowel in this word was with the GB NURSE-vowel /3:/ (40\%), while only 1 student (2\%) pronounced the word with the GB LOT-vowel. The correct pronunciation in the first reading of the GB STRUT-vowel in words young and come was $92 \%$ and $84 \%$, respectively. The mean values show that $18.7 \%$ of participants mispronounced the GB STRUT-vowel with the GB NURSE-vowel /3:/, and 3.3\% with the GB LOT-vowel.

In the second reading, the mean value of correct pronunciation of the GB STRUTvowel increased by $10.7 \%$ to $88.7 \%$. The mean value of mispronunciation of the vowel by the GB stRUT vowel was $10 \%$, and $1.3 \%$ by the GB LOT-vowel. 
TABLE 4. Replacement of the GB strut vowel by /3:/ or / $/$ /

\begin{tabular}{|c|c|c|c|c|c|c|}
\hline \multicolumn{4}{|c|}{ Reading 1} & \multicolumn{3}{|l|}{ Reading 2} \\
\hline Word & Correct $\%$ & /3:/ \% & $/ \mathrm{p} / \%$ & Correct $\%$ & /3:/ \% & $/ \mathrm{p} / \%$ \\
\hline 'lnvli & 58 & 40 & 2 & 78 & 22 & 0 \\
\hline 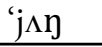 & 92 & 8 & 0 & 96 & 4 & 0 \\
\hline $\mathrm{k} \wedge \mathrm{m}$ & 84 & 8 & 8 & 92 & 4 & 4 \\
\hline Mean & 78 & 18.7 & 3.3 & 88.7 & 10 & 1.3 \\
\hline
\end{tabular}

Mispronunciation of the GB centring diphthongs / $/ \mathrm{\sigma} /$, /ı/, and /eə/ by StS monophthongs $/ \mathrm{u} /, / \mathrm{i} /$, and $/ \varepsilon /$ was expected to occur in words tourists, near and air. As presented in Table 5, the average correct pronunciation of the three centring diphthongs is $50.7 \%$ in the first reading. The weakest performance was the word tourists where $66 \%$ of the participants replaced the diphthong /və/ or the alternative long monophthong / $\mathrm{s} / /$ with the StS monophthong /u/. Mispronunciation of the word air with the StS monophthong / $/ \varepsilon /$ came second with only $50 \%$ of correct pronunciations $^{6}$. The word near came third with $68 \%$ of correct pronunciation, while $32 \%$ of the participants pronounced the diphthong in question as the combination of the $\mathrm{StS}$ monophthong $/ \mathrm{i} /$ and $/ \mathrm{r} /$.

In the second reading, the average correct pronunciation increased to $68 \%$. The pronunciation of the word tourists remains to be most problematic since only $10 \%$ of the participants improved it whereas the percentage of correct pronunciation of the other two diphthongs in the words near and air raised by $14 \%$ and $28 \%$, respectively.

TABLE 5. GB Centring diphthongs pronounced by StS monophthongs followed by $/ \mathrm{r} /$.

\begin{tabular}{|c|c|c|c|c|c|c|c|c|c|c|}
\hline \multicolumn{6}{|c|}{ Reading 1} & \multicolumn{5}{|c|}{ Reading 2} \\
\hline Word & $\begin{array}{c}\text { Correct } \\
\%\end{array}$ & $\begin{array}{c}\text { /ur/ } \\
\%\end{array}$ & $\begin{array}{c}\text { /ir/ } \\
\%\end{array}$ & $\begin{array}{c}\mid \varepsilon r / \\
\%\end{array}$ & $\begin{array}{c}/ \varepsilon: / \\
\%\end{array}$ & $\begin{array}{c}\text { Correct } \\
\%\end{array}$ & $\begin{array}{c}\text { /ur/ } \\
\%\end{array}$ & $\begin{array}{c}/ \text { ir/ } \\
\%\end{array}$ & $\begin{array}{c}/ \varepsilon r / \\
\%\end{array}$ & $\begin{array}{c}/ \varepsilon: / \\
\%\end{array}$ \\
\hline $\begin{array}{l}\text { 'tuərists } \\
\text { 'to:rIsts }\end{array}$ & 34 & 66 & & & & 44 & 56 & & & \\
\hline 'nIə & 68 & & 32 & & & 82 & & 18 & & \\
\hline 'еә & 50 & & & 40 & 10 & 78 & & & 20 & 2 \\
\hline Mean & 50.7 & & & & & 68 & & & & \\
\hline
\end{tabular}

The results presented in Table 6 show that the pronunciation of the diphthong /əo/ in the word rolls was quite problematic. In the first reading, $68 \%$ of the participants pronounced the word correctly, whereas $14 \%$ mispronounced the diphthong either as the long GB monophthong /o:/ or a diphthong with a rounded first element

6 If we took into consideration the trend in the pronunciation of the GB diphthong /ea/ as a long front, open-mid monophthong / $\varepsilon$ :/, then the percentage of correct pronunciations would increase to $60 \%$. 
instead of the central fist element. Pronunciation with the GB LOT-vowel occurred in $4 \%$ of the participants.

In the second reading, the correct pronunciation increased by $14 \%$ to $82 \%$. Mispronunciations with either the long GB monophthong / $/$ :/ or a diphthong with a rounded first element instead of the central fist element prevail.

TABLE 6. The pronunciation of the GB diphthong /əo/.

\begin{tabular}{|l|c|c|c|c|c|c|c|c|}
\hline Reading 1 & \multicolumn{1}{l|}{ Reading 2 } \\
\hline Word & $\begin{array}{c}\text { Correct } \\
\%\end{array}$ & $\begin{array}{c}/ \mathrm{o} / / \\
\%\end{array}$ & $\begin{array}{c}/ \mathrm{p} / \\
\%\end{array}$ & $\begin{array}{c}/ \text { ou/ } \\
\%\end{array}$ & $\begin{array}{c}\text { Correct } \\
\%\end{array}$ & $\begin{array}{c}/ \mathrm{o} / / \\
\%\end{array}$ & $\begin{array}{c}/ \mathrm{p} / \\
\%\end{array}$ & $\begin{array}{c}/ \mathrm{ou} / \\
\%\end{array}$ \\
\hline 'rəolz & 68 & 14 & 4 & 14 & 82 & 8 & 2 & 8 \\
\hline
\end{tabular}

\subsection{Errors in Consonants}

The GB voiced / $/$ and voiceless / $\theta /$ dental fricatives occurred in words the and Thelma. Table 7 shows that in the first reading $84 \%$ of participants correctly pronounced both definite articles, whereas the correct pronunciation of the voiceless dental fricative in the word Thelma was achieved by only $64 \%$ of participants. This means that $16 \%$ of the participants replaced the voiced dental fricative in the definite article by the StS voiced dental plosive /d/, while $36 \%$ of the participants pronounced the $\mathrm{St} S$ voiceless dental fricative in the word Thelma as the voiceless dental plosive $/ \mathrm{t} /$.

In the second reading, the percentage of correct pronunciation of the GB voiced dental fricative $/ \partial /$ in the definite article the remained unchanged. The correct pronunciation of the GB voiceless dental fricative $/ \theta /$ in the word Thelma increased by $12 \%$, while the remaining $24 \%$ of the participants retained the StS voiceless dental plosive.

TABLE 7. Pronunciation of the GB dental fricatives.

\begin{tabular}{|l|c|c|c|c|c|c|}
\hline Reading 1 & \multicolumn{5}{|c|}{ Reading 2 } \\
\hline Word & $\begin{array}{c}\text { Correct } \\
\%\end{array}$ & $\begin{array}{c}/ \mathrm{t} / \\
\%\end{array}$ & $\begin{array}{c}/ \mathrm{d} / \\
\%\end{array}$ & $\begin{array}{c}\text { Correct } \\
\%\end{array}$ & $\begin{array}{c}/ \mathrm{t} / \\
\%\end{array}$ & $\begin{array}{c}/ \mathrm{d} / \\
\%\end{array}$ \\
\hline ðə & 84 & & 16 & 84 & & 16 \\
\hline${ }^{\prime} \theta$ elmə & 64 & 36 & & 76 & 24 & \\
\hline Mean & $\mathbf{7 4}$ & & & $\mathbf{8 0}$ & & \\
\hline
\end{tabular}

Table 8 shows that in the first reading the pronunciation of the GB voiceless glottal fricative / $\mathrm{h} /$ in the word lighthouse was correct in $90 \%$ of participants. Only $10 \%$ replaced the sound with the $S \mathrm{t} S$ voiceless velar fricative $/ \mathrm{x} /$.

In the second reading, the percentage of correct pronunciation increased by $6 \%$, with only $4 \%$ of participants pronouncing the GB voiceless glottal fricative as the $\mathrm{St} S$ voiceless velar fricative. 
TABLE 8. Pronunciation of the GB voiceless glottal fricative $/ \mathrm{h} /$.

\begin{tabular}{|l|c|c|c|c|}
\hline \multicolumn{4}{|l|}{ Reading 1 } & \multicolumn{2}{|c|}{ Reading 2 } \\
\hline Word & Correct & $\begin{array}{c}\text { /x/ } \\
\%\end{array}$ & Correct & $\%$ \\
& $\%$ & $\%$ & $\%$ & $\%$ \\
\hline 'larthaus & 90 & 10 & 96 & 4 \\
\hline
\end{tabular}

As shown in Table 9, the pronunciation of the GB voiced velar nasal $/ \mathrm{y} /$ in words young and searching was in the first reading characterised by adding either the voiced velar plosive /g/ in the word young or the voiceless velar plosive / $/ \mathrm{k} /$ in the word searching. In both words this mispronunciation occurred in $26 \%$ of participants. The remaining $74 \%$ of participants pronounced the words correctly.

In the second reading, the mean value of correct pronunciation increased by $20 \%$. The pronunciation of the GB voiced velar nasal followed by the voiced velar plosive $\mathrm{lg} /$ in the word young remained with $8 \%$ of participants, whereas the pronunciation of the GB voiced velar nasal followed by the voiceless velar plosive $/ \mathrm{k} /$ in the word searching was noticed with $4 \%$ or participants.

TABle 9. Pronunciation of the voiced velar nasal $/ \mathrm{y} . /$

\begin{tabular}{|l|c|c|c|c|c|c|}
\hline Reading 1 & \multicolumn{5}{|c|}{ Reading 2 } \\
\hline Word & $\begin{array}{c}\text { Correct } \\
\%\end{array}$ & $\begin{array}{c}/ \mathrm{gg} / \\
\%\end{array}$ & $\begin{array}{c}/ \mathrm{yk} / \\
\%\end{array}$ & $\begin{array}{c}\text { Correct } \\
\%\end{array}$ & $\begin{array}{c}/ \mathrm{gg} / \\
\%\end{array}$ & $\begin{array}{c}/ \mathrm{jk} / \\
\%\end{array}$ \\
\hline $\mathrm{j} \wedge \mathrm{y}$ & 74 & 26 & & 92 & 8 & \\
\hline 's3:tfin & 74 & & 26 & 96 & & 4 \\
\hline Mean & 74 & & & $\mathbf{9 4}$ & & \\
\hline
\end{tabular}

Pronunciation of the GB voiced post-alveolar approximant/r/ resulted in two types of errors: pronunciation of the sound in positions before a consonant or silence, and the lack of its pronunciations in the position before a vowel, the so-called linking $/ \mathrm{r} /$. Tables 10 and 11 show the results of both mispronunciations of the sound in question.

The results of the first reading indicate that on average $71.25 \%$ of participants pronounced the GB voiced post-alveolar approximant $/ \mathrm{r} /$ in all distributions correctly. Its pronunciation in non-pre-vocalic positions was most frequent in words keepers (44\%), near (48\%), and air (40\%), whereas in daughter (26\%), searching (10\%) and for $(16 \%)$ the pronunciation of $/ \mathrm{r} /$ was less frequent.

The results of the second reading show that on average $86 \%$ of participants pronounced the GB voiced post-alveolar approximant $/ \mathrm{r} /$ in all distributions correctly. The pronunciation of the consonant in pre-vocalic positions in the word keepers decreased by $26 \%$, in the word near by $30 \%$, and in the word air by $20 \%$. Results also indicate improved pronunciation in words daughter by $16 \%$, searching by $2 \%$, and for by $4 \%$. 
There were two instances of linking $/ \mathrm{r} /$ in the sentence: far and and treasure on. As presented in Table 11, results of the first reading show that the omission of linking $/ \mathrm{r} /$ in far and occurred with $46 \%$ of participants, while the pronunciation of the linking $/ \mathrm{r} /$ in treasure on occurred in all participants.

In the second reading, the pronunciation of the linking $/ \mathrm{r} /$ in far and increased by $20 \%$, while its pronunciation in treasure on remained unchanged.

TABLE Io. Pronuniation of the GB voiced post-alveolar approximant $/ \mathrm{r} /$.

\begin{tabular}{|l|c|c|c|c|}
\hline \multicolumn{2}{|l|}{ Reading 1 } & \multicolumn{2}{c|}{ Reading 2 } \\
\hline Word & $\begin{array}{c}\text { Correct } \\
\%\end{array}$ & $\begin{array}{c}/ \mathrm{r} /+\mathrm{C} / 0 \\
\%\end{array}$ & $\begin{array}{c}\text { Correct } \\
\%\end{array}$ & $\begin{array}{c}/ \mathrm{r} /+\mathrm{C} / 0 \\
\%\end{array}$ \\
\hline 'ki:pəz & 56 & 44 & 82 & 18 \\
\hline 'də:tə & 74 & 26 & 90 & 10 \\
\hline 'nıə & 52 & 48 & 82 & 18 \\
\hline 'eə & 60 & 40 & 80 & 20 \\
\hline 's3:tfry & 90 & 10 & 92 & 8 \\
\hline fə & 84 & 16 & 88 & 12 \\
\hline Mean & $\mathbf{6 9 . 3}$ & & $\mathbf{8 5 . 7}$ & \\
\hline
\end{tabular}

TABLE I I. Pronunciation of linking $/ \mathrm{r} /$.

\begin{tabular}{|l|c|c|c|c|}
\hline \multicolumn{2}{|l|}{ Reading 1 } & \multicolumn{2}{c|}{ Reading 2 } \\
\hline Word & $\begin{array}{c}\text { Correct } \\
\%\end{array}$ & $\begin{array}{c}\text { No } \\
\text { linking/r/ }\end{array}$ & $\begin{array}{c}\text { Correct } \\
\%\end{array}$ & $\begin{array}{c}\text { No } \\
\text { linking/r/ }\end{array}$ \\
\hline 'fa:r ən & 54 & 46 & 74 & 26 \\
\hline 'trejər pn & 100 & & 100 & \\
\hline Mean & 77 & & $\mathbf{8 7}$ & \\
\hline
\end{tabular}

\subsection{Errors in Allophonic Features}

Among the predicted errors in allophonic features, only two were detected. The first one is lack of aspiration of voiceless plosives, the second one is the fortition of the voiced obstruents when they occur before voiceless and fortis obstruents or when they are in word-final positions. Interestingly, the dark allophone of /1/ in words Thelma and rolls was correctly pronounced by all participants. The lack of glottal reinforcement of voiceless plosives $/ \mathrm{t} /$ and $/ \mathrm{k} /$ in words lighthouse, makes, as well as the voiceless affricate $/ \mathrm{g} /$ in the word beach, was not detected either.

Lack of aspiration was noticeable in the word tourists. The results in Table 12 show that in the first reading more than half $(54 \%)$ of the participants pronounced the wordinitial voiceless alveolar plosive / $\mathrm{t} / \mathrm{without}$ aspiration. In the second reading, only $10 \%$ of participants improved their pronunciation, while $44 \%$ of them continue to pronounce the initial voiceless alveolar plosive / $\mathrm{t} /$ in the word tourist without aspiration. 
TABLE 12. Lack of aspiration.

\begin{tabular}{|l|c|c|c|c|}
\hline \multicolumn{4}{|c|}{ Reading 1 } & Reading 2 \\
\hline Word & $\begin{array}{c}\text { Correct } \\
\%\end{array}$ & $\begin{array}{c}\text { No aspiration } \\
\%\end{array}$ & $\begin{array}{c}\text { Correct } \\
\%\end{array}$ & $\begin{array}{c}\text { No aspiration } \\
\%\end{array}$ \\
\hline $\begin{array}{l}\text { 't }{ }^{\mathrm{h}} \text { UərIsts } \\
\text { 't } \mathrm{t} \text { \%:rIsts }\end{array}$ & 46 & 54 & 56 & 44 \\
\hline
\end{tabular}

As mentioned in 3.3, fortition of voiced obstruents when they occur in a word-final position or before another voiceless obstruent is a very frequent pronunciation error made by Slovene speakers of English. There are five words in the sentence, which end in a voiced obstruent (keepers, crab, rolls, good, food) and one word (lobster) in which the first syllable ends in a voiced plosive, while the second syllable begins with a voiceless fricative. Results in Table 13 show that in the first reading the mean value of correct pronunciation was $65.2 \%$. Least problematic were the words good and food where the percentage of correct pronunciation was $84 \%$, whereas the word lobster, was mispronounced by $62 \%$ of participants.

In the second reading, the mean value of correct pronunciations increased by $18.4 \%$. The pronunciation of the word lobster improved by $30 \%$. Significant improvement occured with the words keepers (32\%), crab (26\%) and, rolls (18\%).

TABLE 13. Fortition of the voiced obstruents.

\begin{tabular}{|l|c|c|c|c|c|c|c|c|c|c|}
\hline \multicolumn{1}{|l|}{ Reading 1 } \\
\hline Word & Correct \% & $\mathrm{s} \%$ & $\mathrm{ps} \%$ & $\mathrm{p} \%$ & $\mathrm{t} \%$ & Correct \% & $\mathrm{s} \%$ & $\mathrm{ps} \%$ & $\mathrm{p} \%$ & $\mathrm{t} \%$ \\
\hline 'ki:pəz & 50 & 50 & & & & 82 & 18 & & & \\
\hline 'kræb & 66 & & & 34 & & 92 & & & 8 & \\
\hline 'lobstə & 38 & & 62 & & & 68 & & 32 & & \\
\hline 'rəolz & 42 & 58 & & & & 60 & 40 & & & \\
\hline 'god & 84 & & & & 16 & 92 & & & & 8 \\
\hline 'fu:d & 84 & & & & 16 & 92 & & & & 8 \\
\hline Mean & $\mathbf{6 5 . 2}$ & $\mathbf{5 4}$ & & & $\mathbf{1 6}$ & $\mathbf{8 3 . 6}$ & $\mathbf{2 9}$ & & & $\mathbf{8}$ \\
\hline
\end{tabular}

\subsection{Errors in Features of Connected Speech}

There were two types of errors related to the connected speech: the absence of linking $/ \mathrm{r} /$ and the use of strong forms of grammatical items. The usage of the linking $/ \mathrm{r} /$ is presented in Table 11, whereas Table 14 shows the results of the usage of weak as opposed to strong forms.

In the first reading, the mean value of correct pronunciation of function words with their weak forms was only $39.4 \%$. In the second reading, the percentage of correct pronunciation increased by $18.4 \%$. 
The conjunction and appears three times in the sentence and the percentage of its weak pronunciation varied according to its position in the sentence. The percentage of weak pronunciation was better in the closely bound phrase far and near (64\% in the first reading) than in the other two distributions: crab and lobster and good food and searching (both $40 \%$ in the first reading). In the second reading, the pronunciation with the weak vowel /ə/ increased to $86 \%$ in case of far and near, and to $80 \%$ in the other two distributions of the conjunction and.

In the first reading, the prepositions from and for were correctly pronounced by $22 \%$ and $32 \%$, respectively. In the second reading, their correct pronunciation increased by $64 \%$ in case of from, and $54 \%$ in case of for.

TABLE 14. Usage of weak forms.

\begin{tabular}{|c|c|c|c|c|c|c|c|c|c|c|c|c|c|c|}
\hline \multicolumn{8}{|c|}{ Reading 1} & \multicolumn{7}{|c|}{ Reading 2} \\
\hline Word & $\begin{array}{l}\delta^{\circ} \\
\ddot{u} \\
\ddot{U} \\
0 \\
0\end{array}$ & $\frac{2}{\not 8}$ & 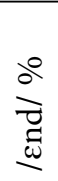 & $\frac{d^{0}}{\stackrel{\vec{E}}{\omega}}$ & $\frac{2}{2}$ & $\frac{\dot{0}^{\circ}}{\dot{e}}$ & 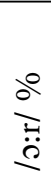 & 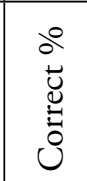 & $\frac{\partial^{\circ}}{\not x}$ & $\begin{array}{l}\partial^{\circ} \\
\vec{\omega} \\
\vec{\omega}\end{array}$ & $\begin{array}{l}d^{0} \\
\stackrel{\vec{E}}{\omega} \\
\dot{\omega}\end{array}$ & $\frac{0^{\circ}}{2}$ & $\frac{\partial}{\ddot{\theta}}$ & 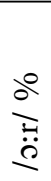 \\
\hline $\begin{array}{l}\text { and / } \\
\text { ənd/, / } \\
\text { ən/ }\end{array}$ & 40 & 0 & 40 & 20 & & & & 80 & 0 & 14 & 6 & & & \\
\hline $\begin{array}{l}\text { from / } \\
\text { from/ }\end{array}$ & 22 & & & & 78 & & & 86 & & & & 14 & & \\
\hline $\begin{array}{l}\text { far and } \\
\text { /ən/ } \\
\text { near }\end{array}$ & 64 & 0 & 36 & & & & & 86 & 0 & 14 & & & & \\
\hline $\begin{array}{l}\text { and / } \\
\text { ənd/, / } \\
\text { ən/ }\end{array}$ & 40 & 0 & 40 & 20 & & & & 80 & 0 & 14 & 6 & & & \\
\hline for / fa/ & 32 & & & & & 52 & 16 & 86 & & & & & 12 & 2 \\
\hline Mean & 39.6 & & & & & & & 83.6 & & & & & & \\
\hline
\end{tabular}

\subsection{Influence of American English}

The pronunciation of the word daughter reflected the influence of American English in three phonemes:

- replacement of the GB NORTH-vowel /っ:/ by the GB LOT-vowel /p/;

- replacement of the GB voiceless alveolar plosive / $\mathrm{t} /$ by the voiced alveolar tap / $\mathrm{t}$ /;

- the pronunciation of the voiced post-alveolar approximant $/ \mathrm{r} /$ in the word-final position and before the initial voiceless dental fricative $/ \theta /$ of the following word Thelma.

As presented in Table 15, only $56 \%$ of participants pronounced the word correctly in the first reading, while $34 \%$ of them mispronounced the vowel, and $4 \%$ used 
the voiced alveolar tap / $\mathrm{t} /$ instead of the voiceless alveolar plosive / $/ \mathrm{t} /$. More than a quarter $(26 \%)$ of participants pronounced the final voiced post-alveolar approximant although the next word began on a consonant.

In the second reading, the percentage of correct pronunciation increased by $20 \%$. Mispronunciation of the first vowel remained with $16 \%$ of participants, whereas the pronunciation of the voiced alveolar tap occurred with only $2 \%$ of participants. The pronunciation of the final voiced post-alveolar approximant in the pre-consonantal position was retained by $10 \%$ of participants.

TABLE 15. Influence of American English.

\begin{tabular}{|l|l|l|l|l|l|l|l|l|}
\hline \multicolumn{4}{|l|}{ Reading 1 } & \multicolumn{4}{l|}{ Reading 2 } \\
\hline Word & Correct $\%$ & $/ \mathrm{p} / \%$ & $/ \mathrm{t} / \%$ & $/ \mathrm{r} / \%$ & Correct $\%$ & $/ \mathrm{p} / \%$ & $/ \mathrm{t} / \%$ & $/ \mathrm{r} / \%$ \\
\hline 'ds:tə & 56 & 34 & 4 & 26 & 76 & 16 & 2 & 10 \\
\hline
\end{tabular}

\section{Discussion}

When interpreting the results, we have to take into consideration that the sample of the participants in both readings was only 50. It is reasonable to assume that the participants who decided to take part in the second test were better than their colleagues who failed to record the sentence at the end of the course. Thus the relatively high mean value of the correct pronunciation of the sentence in the first reading $(66.34 \%)$ can be explained by good pronunciation of the selected participants before they started the course on English phonetics and phonology. The increase of correct pronunciation to $82.48 \%$ in the second reading can be explained by high motivation of the same participants to improve their pronunciation even more and to pass the exam. Nonetheless, the results of the first reading, when the participants read the sentence from the spelling, confirmed nearly all predicted mispronunciations arising from the phonetic and phonological differences between General British English and standard Slovene, as well as the influence of General American (see Table 15). In addition, the influence of the spelling on the pronunciation was particularly noticeable in the word rolls (68\%), and to a much lower percentage in the words lovely (2\%) and come $(8 \%)$ in which the correct GB vowel were mispronounced by either $/ \mathrm{p} /$ or $/ \mathrm{s} / \mathrm{.}$. This additionally confirms the findings of previous studies (Komar 2017; Šuštaršič 2005) which suggested that the orthography had a misleading effect on the pronunciation. Results of the second reading indicate a significant improvement particularly in case of the word rolls when $82 \%$ of participants pronounced the correct diphthong. We believe that this improvement, as well as all other improvements of pronunciation in the second reading mentioned below, are the result of systematic training of perception and production of GB sounds, as well as phonemic transcription, and as such, confirm our second hypothesis. 
There was only one instance of a long GB monophthong followed by a voiced consonant (food) which, as predicted, would be mispronounced by the participants as too short. However, this did not happen. The vowel was in the first reading correctly pronounced by $92 \%$ of participants. On the other hand, the GB FOOTvowel, which occurred in the word good, was pronounced with the StS /u/ vowel by $30 \%$ of participants. In the second reading the correct pronunciation increased by $18 \%$ to $82 \%$.

In line with the studies by Stopar $(2015,2019)$ and Komar (2017), which found that the GB TRAP vowel is the most difficult vowel for Slovene speakers to perceive and produce correctly, the results of the present study confirm these findings. The percentage of correct pronunciation of the word $c r a b$ in the first reading was at $66 \%$. Systematic training of pronunciation and phonemic transcription, as well as highly predictable spelling of the vowel by the letter $<a>$, resulted in an increase of correct pronunciation of the word in the second reading to $92 \%$.

It was predicted that GB centring diphthongs/ı/, /eə/ and/ひə/ would be pronounced by $\mathrm{StS}$ monophthongs $/ \mathrm{i} /, / \varepsilon /$ and $/ \mathrm{u} /$ followed by $/ \mathrm{r} /$. In the three words which had the three GB centring diphthongs (tourists, near, air), the mean value of correct pronunciation was $50.7 \%$ in the first reading, and raised to $68 \%$ in the second reading. The average improvement in the second reading was thus only $17.3 \%$. Although there are no studies available which would look into the relationship between perception and production of these three diphthongs by Slovene speakers of English, we suggest two main reasons for these mispronunciations: first, the lack of the centring diphthongs or their near equivalents in L1, and second, the influence of the spelling, particularly the letter $<\mathrm{r}>$, which was present in all three words.

Although the spelling of the two GB dental fricatives by the letters $<$ th $>$ is highly predictable, $36 \%$ of the participants pronounced the GB voiceless dental fricative / $\theta$ / in the word Thelma as the StS voiceless dental plosive / $t /$ in the first reading. With a lot of pronunciation training, the pronunciation in the second reading improved by $12 \%$. The GB voiced dental fricative /ð/ occurred only in the definite article the which was preceded by words ending on the voiced alveolar nasal $/ \mathrm{n} /$ (when the, on the). In Slovene the nasal has dental place of articulation rather than alveolar which resulted in the pronunciation of the GB voiced dental fricative / $/$ / as the voiced dental plosive /d/ by $84 \%$ of participants in both readings.

Theoretical instructions, systematic training of perception and production, as well as phonemic transcription had a positive influence on the correction of the pronunciation of the GB voiced velar nasal $/ \mathrm{y} /$ when it is not followed by the GB voiced velar plosive $/ \mathrm{g} /$. In the first reading, $74 \%$ of participants pronounced the GB velar nasal in the word young together with the voiced velar plosive $/ g /$, and in the 
word searching together with the voiceless velar plosive $/ \mathrm{k} /$. In the second reading, the mean value of the correct pronunciation reached $94 \%$.

Another pronunciation feature, which was at the beginning of the course in English phonetics and phonology present on average in $69.3 \%$ of participants, was the pronunciation of the $\mathrm{GB}$ voiced post-alveolar approximant $/ \mathrm{r} /$ in word final or pre-consonantal positions. Reasons for that are to be found both in the spelling, as well as in the influence of General American pronunciation. Systematic training of production and phonemic transcription had a positive influence on the second reading when $85.7 \%$ of participants pronounced the words keepers, daughter, lobster, near, air, searching, and for without the post-vocalic $/ \mathrm{r} /$.

The two allophonic variations of GB obstruents, which are for Slovene speakers of English very difficult to master, are aspiration and devoicing of voiced obstruents in word-final position or before another voiceless consonant. Aspiration, which is not a feature of the standard Slovene language, proved to be particularly challenging. In the period between the two tests only $10 \%$ of participants acquired this important feature, while the percentage of correctly pronounced voiceless alveolar plosive in the word tourists reached 56\% (see Table 11). The pronunciation of devoiced and lenis obstruents in the word final position or before another voiceless consonant on average improved by $18.4 \%$, reaching $83.6 \%$ in the second reading.

There is no doubt that systematic training of phonemic transcription resulted in a significant increase ( $44 \%$ on average) in the usage of the weak forms of function words.

Another manifestation of the benefit of systematic pronunciation teaching is the awareness of the difference between standard British English and General American. The influence of the latter was most noticeable in the word daughter when only $56 \%$ of participants pronounced the word using standard British English pronunciation in the first reading. In the second reading, the percentage raised to $76 \%$ which means a $20 \%$ increase (see Table 15 ).

\section{Conclusion}

The main purpose of our study was to test the amount of improvement and development of General British pronunciation of Slovene students of English after a 60-hour intensive theoretical and practical course of English phonetics and phonology. With that in mind, the first-year students of the BA level were asked to read and record an English sentence, which contained all GB sounds, before and after the course. In the end, we selected 50 same students who took part in both tests.

Although the results of the first reading showed an overall high competence in GB pronunciation, they nonetheless confirmed our first hypothesis that L1 interference, 
orthography and General American pronunciation will be more numerous in the first reading of the sentence. Pronunciation of individual sounds, which previous studies mentioned as most problematic, turned out to be problematic also in the first reading of the sentence. Overall results of the second reading improved which confirms our second hypothesis that systematic pronunciation training which includes theoretical knowledge, phonemic and phonetic transcription, as well as perception and production of individual sounds, has positive effects on the acquisition of foreign sounds. Our study also showed that some allophonic features (e.g. aspiration) are more difficult to acquire than others (e.g. devoicing and lenition of final voiced obstruents). The benefit of practising phonemic transcription and reading from it is certainly visible in the fact that the best improvement was achieved in the acquisition of weak forms of function words.

Although both our hypotheses were confirmed, two reservations have to be mentioned. First, the students whose readings were analysed probably do not represent the average competence of all our first-year students. It is safe to claim that our sample of participants consisted of highly motivated students whose initial English pronunciation competence was above average. Their results after the second reading indicate that they were also highly motivated to improve their English pronunciation.

Our second reservation concerns the sentence which the participants had to read. Although it contained all GB sounds, it did not contain certain problematic features for Slovene EFL learners, such as non-reduced long GB vowels. This is why we suggest that future research in the production of GB sounds should focus on the acquisition of foreign allophonic features in more defined contexts, ranging from individual syllables to phrases and sentences. In addition, future research of pronunciation should also move away from reading to spontaneous speech.

\section{References}

Baker, Wendy, Pavel Trofimovich. 2006. "Perceptual paths to accurate production of L2 vowels: the role of individual differences." International Review of Applied Linguistics in Language Teaching 44 (3): 231-50. http://dx.doi.org/10.1515/IRAL.2006.010.

Bassetti, Benedetta. 2008. "Orthographic input and second language phonology." In Input Matters in SLA, edited by Thorsten Piske and Martha Young-Scholten, 191-206. Clevedon, UK: Multilingual Matters.

Best, Catherine T. 1995. “A Direct Realist View of Cross-Language Speech Perception.” In Speech Perception and Linguistic Experience: Theoretical and Methodological Issues, edited by Winifred Strange, 171-203. Baltimore: York Press.

Bion, Ricardo A. H., Paola Escudero, Andréia S. Rauber, and Barbara O. Baptista. 2006. "Category Formation and the Role of Spectral Quality in the Perception and Production of English Front Vowels." Proceedings of Interspeech 2006, 1363-6. Pittsburgh: Interspeech.

Collins, Beverly, Rastislav Šuštaršič, and Smiljana Komar. 2014. Present-Day English Pronunciation: A Guide for Slovene Students. Revised and Enlarged 2nd Edition. Ljubljana: Znanstvena založba Filozofske fakultete, Oddelek za anglistiko in amerikanistiko. 
Cruttenden, Alan. 2014. Gimson's Pronunciation of English. 8th Edition. Abingdon: Routledge.

Escudero, Paola. 2002. "The Perception of English Vowel Contrasts: Acoustic Cue Reliance in the

Development of New Contrasts." In New Sounds 2000: Proceedings of the Fourth International Symposium on the Acquisition of Second-Language Speech, Klagenfurt, edited by Allan James and Jonathan Leather, 122-31. Klagenfurt: University of Klagenfurt.

Flege, James E. 1995. “Second Language Speech Learning: Theory, Findings and Problems.” In Speech Perception and Linguistic Experience: Issues in Cross-Language Research, edited by Winifred Strange, 233-277. Timonium, MD: York Press.

Komar, Smiljana. 2017. "The Relationship between the Perception and Production of Four General British Vowels by Slovene University Students of English.” Linguistica 57 (1): 161-70. https://doi. org/10.4312/linguistica.57.1.161-170.

Lipinska, Dorota. 2013. "Influence of Formal Instruction in English Phonetics and Phonology on Polish Learners' Production of English /TRAP/." In Proceedings of the Phonetics Teaching and Learning Conference, UCL, London, 8-10 August 2013, 59-62. London: Phonetics Teaching and Learning Conference.

Lintunen, Pekka. 2005. "Phonemic Transcription and Its Effect on Learning." In Proceedings of the Phonetics Teaching and Learning Conference 2005, edited by John A. Maidment, 1-4. London: University College London.

Lord, Gillian. 2005. "(How) Can We Teach Foreign Language Production? On the Effects of a Spanish Phonetics Course.” Hispania 88 (3): 557-67. http://www.jstor.org/ stable/20063159.

Matthews, John, and Cynthia Brown. 2004. "When Intake Exceeds Input: Language Specific Perceptual Illusions Induced by L1 Prosodic Constraints." International Journal of Bilingualism 8 (1): 5-27. http://dx.doi.org/10.1177/1367006904 0080010201

Stopar, Andrej. 2015. "Perception of Four General British Vowels by Slovenian University Students of English as a Foreign Language." In PTLC2015: Proceedings of the Phonetics Teaching and Learning Conference, London, 5-7 August 2015, 87-90. London: Phonetics Teaching and Learning Conference.

—. 2017. "Perception of the GB Vowels [...] by Slovenian Speakers of English. In PTLC2017: Proceedings of the Phonetics Teaching and Learning Conference UCL, London, 9-11 August 2017, 104-9. London: Phonetics Teaching and Learning Conference.

—. 2019 [forthcoming]. "Perception of General British Monophthongs: The Case of Slovene Students of English as a Foreign Language." Jezikoslovlje.

Šuštaršič, Rastislav. 2005. English-Slovene Contrastive Phonetic and Phonemic Analysis and Its Application in Teaching English Phonetics and Phonology. Ljubljana: Znanstveni inštitut Filozofske fakultete.

Šuštaršič, Rastislav, Smiljana Komar, and Bojan Petek. 1999. "Slovene." In Handbook of the International Phonetic Association, A Guide to the Use of the International Phonetic Alphabet, 135-139. Cambridge: Cambridge University Press.

Wells, John C. 1996. "Why Phonetic Transcription Is Important." Malsori (Phonetics), the Journal of the Phonetic Society of Korea 31-32, 239-42.

—. 1982. Accents of English. Cambridge: Cambridge University Press. 